\author{
JADWIGA WARDAS, BARBARA KOSMOWSKA \\ Zakład Neuropsychofarmakologii \\ Instytut Farmakologii im. J. Maja PAN \\ Smętna 12, 31-343 Kraków \\ E-mail: wardas@if-pan.krakow.pl
}

\title{
ZABURZENIA FAZY SNU REM JAKO WCZESNY MARKER CHOROBY PARKINSONA*
}

\section{WPROWADZENIE}

Choroby neurodegeneracyjne stanowia rosnace zagrożenie dla zdrowia w demograficznie starzejacych się społeczeństwach i jedno $z$ globalnych wyzwań XXI w. Wiadomo, że liczba przypadków tych chorób rośnie $z$ roku na rok i uważa się, że na świecie choruje na nie co najmniej $50 \mathrm{mln}$ osób. Również w Polsce wzrasta liczba osób w wieku powyżej 60 r. życia i według prognoz w 2030 r. będzie ich już ponad $9 \mathrm{mln}$. Choroby te stanowia bardzo ważna grupę schorzeń mózgu, związana głównie $z$ wiekiem, o różnej etiologii, ale ze wspólnym patomechanizmem, polegajacym na uszkodzeniu neuronów. Wśród najczęściej występujacych i najpoważniejszych chorób neurodegeneracyjnych, poza głównymi, czyli choroba Alzheimera (AD) i choroba Parkinsona (PD), sa także m.in. stwardnienie zanikowe boczne (ang. amyotrophic lateral sclerosis, ALS), zanik wieloukładowy (ang. multiple system atrophy, MSA), postępujące porażenie nadjądrowe (ang. progressive supranuclear palsy, PSP), pląsawica Huntingtona (ang. Huntington disease, HD), otępienie $z$ ciałami Lewy'ego (ang. dementia with Lewy bodies, LBD) $i$ inne. Nie wszystkie przyczyny powstawania oraz mechanizmy tych chorób zostały poznane. Jednak wiele $z$ nich cechuje nieprawidłowe nagromadzanie się $\mathrm{w}$ różnych obszarach mózgu zdegenerowanych form białek, utworzonych w wyniku agregacji. Nie sa one rozkładane przez enzymy proteolityczne i dlatego tworza nierozpuszczalne złogi. Na- dal jednak nie jest jasny mechanizm, który zapoczatkowuje proces agregacji białek.

Choroby neurodegeneracyjne rozwijaja się i przebiegaja przewlekle, prowadzac do wielu różnych deficytów zwiazanych $z$ uszkodzeniami w układzie nerwowym. Sa one bowiem zbyt późno diagnozowane, gdy zwyrodnieniu ulegnie już wiele specyficznych dla danej choroby neuronów i wyczerpią się możliwości plastyczne mózgu, natomiast pojawia się określone objawy, głównie ruchowe, takie jak niedowłady, niezborność, spastyczność, spowolnienie ruchowe (bradykinezja), sztywność mięśniowa czy ruchy mimowolne. Poza zaburzeniami ruchowymi pojawiaja się również zaburzenia funkcji poznawczych, otępienie, objawy psychotyczne czy zaburzenia snu. Fakt późnego wykrywania tych chorób wyjaśnia niską skuteczność obecnie istniejacych terapii objawowych oraz poszukiwanie wczesnej diagnostyki i terapii profilaktycznych, mogących wydłużyć przedkliniczny etap jeszcze stosunkowo komfortowego życia. W zwiazku z tym, również $\mathrm{w}$ naszym kraju, problem odpowiedniej diagnostyki i terapii schorzeń wieku starczego nabiera ogromnej wagi.

\section{CHOROBA PARKINSONA}

Choroba Parkinsona została opisana pierwszy raz w 1817 r. przez Jamesa Parkinsona i określana była dawniej jako „drżaczka poraźna" (ang. shaking palsy). Według pierwszej definicji J.-M. Charcot (1861 r., sugestia użycia nazwy „Parkinson's Dise-

Słowa kluczowe: choroby neurodegeneracyjne, choroba Parkinsona, faza prodromalna, objawy pozaruchowe, objawy ruchowe, RBD - zaburzenia zachowania w fazie snu REM, zaburzenia snu

*Praca powstała w ramach finansowania $z$ funduszy statutowych Zakładu Neuropsychofarmakologii, Instytutu Farmakologii im. J. Maja PAN w Krakowie. 
ase"), choroba ta była określona jako schorzenie neurologiczne $z$ drżeniem, sztywnościa i spowolnieniem ruchowym (parkinsonizm). $Z$ kolei według ostatnich, klinicznych kryteriów Movement Disorders Society (MDS) (PoSTUMA i współaut. 2015a), PD jest „schorzeniem wielosystemowym $\mathrm{z}$ parkinsonizmem, reagujacym na leczenie dopaminergiczne, $z$ obecnością ciał Lewy'ego, charakteryzujacym się utratą neuronów dopaminowych w części zbitej istoty czarnej (ang. substantia nigra pars compacta, SNc), deficytem neuroprzekaźników i genetycznymi czynnikami ryzyka".

Obecnie uważa się więc, że PD jest choroba o złożonej i niejasnej etiopatogenezie, w której, poza najbardziej znanymi zaburzeniami ruchowymi, obserwuje się także zespół objawów pozaruchowych (ang. non-motor symptoms, NMS) zwiazanych, poza dopamina, $z$ zaburzeniami funkcji niedopaminergicznych (noradrenergicznych, serotoninergicznych, cholinergicznych, glutaminianergicznych czy GABAergicznych), obejmujacy zaburzenia poznawcze (kognitywne), węchu, nastroju, depresje, dysfunkcje autonomiczne, bólowe i czuciowe oraz zaburzenia snu (Tabela 1) (KRYGOWSKA-WAJS 2006, SŁAWEK i współaut. 2006, WIECZOREK i współaut. 2012, OBESO i współaut. 2017, RODRÍGUEZ-VIOLANTE i współaut. 2017, SCHAPIRA i współaut. 2017, Postuma i Berg 2019, Goldman i GuERRA 2020, MUNOZ i współaut. 2020, ZHU i współaut. 2020).

\section{EPIDEMIOLOGIA I CZYNNIKI RYZYKA}

Według obecnych danych PD jest, zaraz po $\mathrm{AD}$, druga co do częstości występowania choroba neurodegeneracyjna $i$, podobnie jak $\mathrm{AD}$, dotyczy przede wszystkim pacjentów po 60. roku życia. Szacuje się, że na świecie liczba chorych zwiększyła się ponaddwukrotnie w latach 1990-2015 do ok. 6,2 $\mathrm{mln}$, a przewiduje się, że do 2040 r. zachoruje na nia ponad $14 \mathrm{mln}$ osób (ARMSTRONG i OKUN 2020, JANKOVIC i TAN 2020, KILZHEIMER i współaut. 2019, OBESO i współaut. 2017). W krajach uprzemysłowionych szacunkowe występowanie PD w populacji ogólnej wynosi ok. $0,3 \%$, natomiast liczba przypadków ro- śnie $\mathrm{z}$ wiekiem i u osób powyżej 60 r. życia wynosi już ok. $1 \%$, a po 80 r. życia aż $3-5 \%$, przy średnim wieku zachorowania ok. 58 lat. Szczyt zachorowań przypada na wiek 85-89 lat (ARMSTRONG i OKUN 2020).

Czynnikami ryzyka w PD, poza najważniejszym, czyli wiekiem, wydaje się być także, choć w umiarkowanym stopniu, płeć, bowiem według dotychczasowych badan mężczyźni chorują nieco częściej niż kobiety (stosunek mężczyzn do kobiet $=1,4: 1,0$ ) (ASCHERIO i SCHWARZSCHILDE 2016). Z ryzykiem zachorowania wiąża się też różne czynniki środowiskowe, jak pestycydy czy życie na wsi, uprawa roli, użycie wody studziennej, a także np. urazy głowy czy cukrzyca typu 2, choć metaanalizy dostarczaja czasem sprzecznych danych (JANKOVIC i TAN 2020) (Ryc. 1). Z kolei niektóre substancje, będące inhibitorami kompleksu I mitochondrialnego łańcucha oddechowego, takie jak 1-metylo-4-fenylo-tetrahydropirydyna (MPTP) czy annonacyna, moga wywoływać śmierć neuronów szlaku czarno-prażkowiowego (ang. nigro-striatal pathway) i parkinsonizm. MPTP stanowi zreszta jeden $z$ ważnych zwiazków używanych do modelowania PD u zwierzat. Także narażenie na toksyczne poziomy np. manganu, trójchloroetylenu, tlenku węgla, może czasami prowadzić do pewnego rodzaju parkinsonizmu, ale o innych cechach patologicznych i klinicznych niż PD. Duży wpływ ma również styl życia, bowiem wykazano istnienie odwrotnego zwiazku między ryzykiem wystapienia $\mathrm{PD}$ a paleniem papierosów, piciem kawy (kofeina), ćwiczeniami fizycznymi (szczególnie $\mathrm{w}$ wieku średnim 4060 lat) czy użyciem zwiazków blokujących kanały wapniowe lub statyn, czyli ich działania ochronne (ASCHERIO i SCHWARZSCHILDE 2016, BALLESTRINO i SCHAPIRA 2020, JANKOVIC i TAN 2020). Natomiast dostępne wyniki badań dotyczace związu między użyciem niesteroidowych leków przeciwzapalnych lub poziomem kwasu moczowego a zachorowaniem na PD dostarczają sprzecznych danych.

Większość przypadków PD to forma sporadyczna (idiopatyczna). Dotychczasowe badania wskazuja jednak na role historii choroby $\mathrm{w}$ rodzinie jako czynnika ryzyka $\mathrm{PD}$,
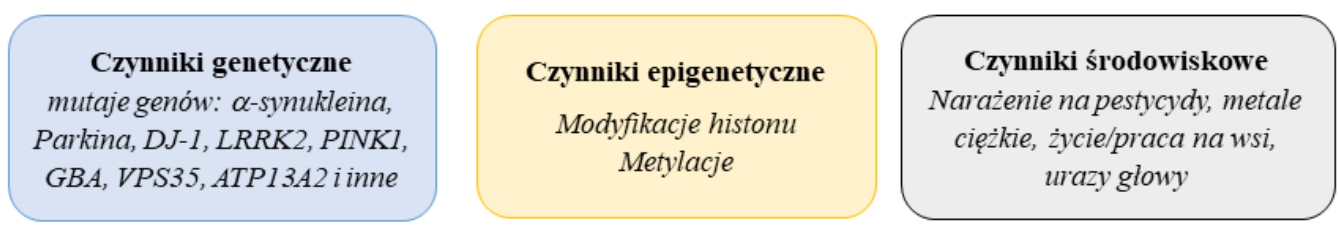

Ryc. 1. Etiologia choroby Parkinsona: interakcja między czynnikami genetycznymi, epigenetycznymi, środowiskowymi oraz inne czynniki jak starzenie i styl życia, leżą u podstaw choroby (wg JANKovic i TAN 2020, zmieniona). 
bowiem wykazano 2- lub 3-krotny wzrost ryzyka zachorowania u krewnych pierwszego stopnia, w porównaniu do kontroli (BALlESTRINO i SCHAPIRA 2020, JANKOVIC i TAN 2020). Zidentyfikowano wiele rodzin, u których występuje dziedziczna forma choroby, a dowodów na udział czynników genetycznych jako przyczyny PD dostarczyły także badania na bliźniętach. Obecnie uważa się, że rodzinne i genetyczne formy PD stanowią od 5-15\% przypadków (BALLESTRINO i SCHAPIRA 2020, JANKOVIC i TAN 2020, UGRUMOV 2020). Pierwszym genem zwiazanym z PD, który został odkryty w 1997 r. była a-synukleina (a-syn). Do chwili obecnej zostało odkrytych ponad 20 monogenetycznych form PD i ponad 100 loci zidentyfikowano jako czynniki ryzyka PD (BALLESTRINO i SCHAPIRA 2020, JANKOVIC i TAN 2020). Wśród najważniejszych genów, których mutacje wywołuja PD, poza $a$-syn, sa też m.in. parkin (najczęśsiej występujący gen, którego mutacje odpowiadaja za ok $50 \%$ przypadków PD o wczesnym początku), LRRK2 (koduje białko kinazy białkowej 2, bogatej w reszty leucynowe, którego mutacja została zidentyfikowana zarówno w rodzinnej, jak i sporadycznej formie PD), GBA (glukocerebrozydaza, koduje enzym lizosomalny, a mutacje w tym genie znaleziono u $10 \%$ chorych ze sporadyczna PD oraz u $40 \%$ pacjentów $z$ rodzinna forma choroby wśród aszkenazyjskich żydów) czy wreszcie PINK1, UCHL1 i inne (BALLESTRINO i SCHAPIRA 2020, JANKOVIC i TAN 2020).

\section{PATOFIZJOLOGIA PD}

Główne cechy patologiczne sporadycznej PD, odkryte $\mathrm{w}$ badaniach pośmiertnych (ang. post mortem), to utrata kontrolujacych funkcje ruchowe i zawierajacych neuromelaninę neuronów dopaminergicznych, z późniejsza depigmentacją części zbitej istoty czarnej (SNc) i obecność ciał Lewy'ego (LB). LB sa wewnatrzneuronalnymi i/lub wewnatrzglejowymi wtrętami (inkluzjami), barwiącymi się hematoksylina-eozyna, $z$ gestym, hialinowym rdzeniem i jasną otoczka, o średnicy ok. 5-25 $\mu \mathrm{m}$. Ich głównymi składnikami, wśród ponad 90 różnych białek, sa a-synukleina, ubikwityna, synfilina-1 (OBESO i współaut. 2017, BALLESTRINO i SCHAPIRA 2020).

Występujaca natywnie $\mathrm{w}$ formie monomerów/tetramerów (struktura a-helisy) a-Syn, ma skłonność do zmiany konformacji $z$ formy a-helisy do nierozpuszczalnych agregatów, bogatych w strukturę $\beta$-kartki. W procesie agregacji tworza się toksyczne formy oligomeryczne i protofibrylarne, które m.in. upośledzają funkcję mitochondriów, lizosomów i proteasomów, uszkadzaja błony biologiczne i cytoszkielet, zmieniaja funkcje synaptyczną i wywołują degenerację neuronów (BALLESTRINO i SCHAPIRA 2020). Szacuje się, że w chwili rozpoznania choroby nawet do $60 \%$ neuronów dopaminergicznych SNc uległo już degeneracji, a w konsekwencji obserwuje się $>70 \%$ spadki neuroprzekaźnika dopaminy w jądrze ogoniastym-łupinie (ang. caudate nucleus - putamen, CP), czyli strukturze mózgu, do której docieraja zakończenia neuronów z SNc (OBESO i współaut. 2017, UGRUMOV 2020). Agregaty a-syn stanowia wspólna cechę schorzeń neurodegeneracyjnych, tzw. synukleinopatii, wśród których, poza $\mathrm{PD}$, sa także LBD, AD, MSA, ALS czy inne jak choroba Picka, Gauchera (OBESO i współaut. 2017, BALLESTRINO i SCHAPIRA 2020).

Według hipotezy Braaka (BRAAK i współaut. 2003, 2004; DEL TREDICI i BRAAK 2016), wczesne zmiany patologiczne (etap 1-2) pojawiaja się najpierw w rdzeniu przedłużonym (ang. medulla oblongata), ruchowym jadrze grzbietowym nerwu błędnego (ang. dorsal motor nucleus of the vagus nerve) oraz opuszkach węchowych (ang. olfactory bulb), czy miejscu sinawym (ang. locus coeruleus). Następnie zmiany te postępuja, rozprzestrzeniając się na struktury pnia mózgu (SNc, śródmózgowie, przodomózgowie), etapy 3-4 stanowia próg, po przekroczeniu którego pojawiaja się kliniczne objawy motoryczne, a na końcowych etapach (5-6) uszkodzeniu ulegaja struktury kory mózgowej i wówczas mamy do czynienia $z$ pełną manifestacja objawów klinicznych PD, zarówno ruchowych, jak też zaburzeń poznawczych czy demencji.

Sugeruje się, że a-syn może rozprzestrzeniać się w układzie nerwowym w sposób prionowy, a ten mechanizm prawdopodobnie leży u podstaw postępu opisanych wcześniej zmian patologicznych (MCCANN i współaut. 2016). Ponadto, dane piśmiennictwa sugeruja, że u osób podatnych, pod wpływem np. czynników środowiskowych (pestycydy, mikroflora jelitowa), najpierw dochodzi do agregacji a-syn w nerwowym układzie jelitowym (ang. enteric nervous system, ENS) i rozprzestrzeniania się synukleinopatii przez nerw błędny $z$ jelit do mózgu, a wpływ na te procesy może mieć mikrobiom jelitowy (BALLESTRINO i SCHAPIRA 2020, ELFIL i współaut. 2020).

Należy też wspomnieć, że niezależnie od udziału czynników środowiskowych i genetycznych w etiologii PD, sugeruje się także (na podstawie badań pośmiertnych, na liniach ludzkich komórek in vitro, w zwierzęcych modelach tej choroby) udział kilku kluczowych procesów/zjawisk, do których, poza agregacja a-syn, należa także dysfunkcja mitochondriów, upośledzenie rozkładu białek (dysfunkcja proteasomów, li- 
zosomów), procesy neurozapalne czy stres oksydacyjny (JANKOVIC i TAN 2020, UGRUMOV 2020). Również inne procesy molekularne i komórkowe, takie jak zaburzenie transportu pecherzykowego, utrata integralności mikrotubul, ekscytotoksyczność, zaburzenie czynników troficznych, leżą u podstaw PD. Zasadniczo wszystkie te mechanizmy potencjalnie prowadza do programowanej śmierci komórek (apoptozy) lub nekrozy. Ponieważ zmiany komórkowe sa dynamiczne, a neurodegeneracja jest procesem długotrwałym i postępującym oraz przebiega w obecności mechanizmów kompensacyjnych, takich jak wzrost aktywności przeżywających neuronów, synteza dopaminy w prążkowiu w neuronach nie-dopaminowych (np. serotoninergicznych, noradrenergicznych) czy kompensacje $z$ udziałem czynników wzrostu, wydaje się, że te różne procesy patofizjologiczne nakładaja się na siebie, prowadząc ostatecznie do nieodwracalnych uszkodzeń komórek (BLESA i współaut. 2017, OBEso i współaut. 2017, JANKOVIC i TAN 2020).

\section{OBRAZ KLINICZNY I PODTYPY PD}

PD, jak już wspomniano wcześniej, jest choroba progresywna, rozwijajaca sie bezobjawowo przez wiele lat, według niektórych autorów nawet do 30 (OBEso i współaut. 2017, UGRumov 2020). Zgodnie $z$ kryteriami MDS (BERG i współaut. 2015, POSTUMA i współaut. 2015a, Postuma i Berg 2019, UGRUMOV 2020) można w niej wyróżnić 3 etapy:

1. Fazę przedkliniczna - gdy procesy neurodegeneracyjne sa już co prawda obecne, ale brak jest mierzalnych objawów;

2. Fazę prodromalną - obejmujacca okres między pierwszymi objawami pozaruchowymi i wystapieniem objawów ruchowych, jeszcze niewystarczających do zdiagnozowania klinicznej postaci PD. Okres ten trwa ok. 10 lat przed wystapieniem parkinsonizmu; według MDS kryteria badawcze dla tej fazy obejmuja m.in. zaburzenie zachowania w fazie snu REM (RBD), osłabienie węchu (hiposmia), depresję i dysautonomię (zaparcia, podciśnienie ortostatyczne, zaburzenia seksualne i układu moczowego) (Ryc. 2).

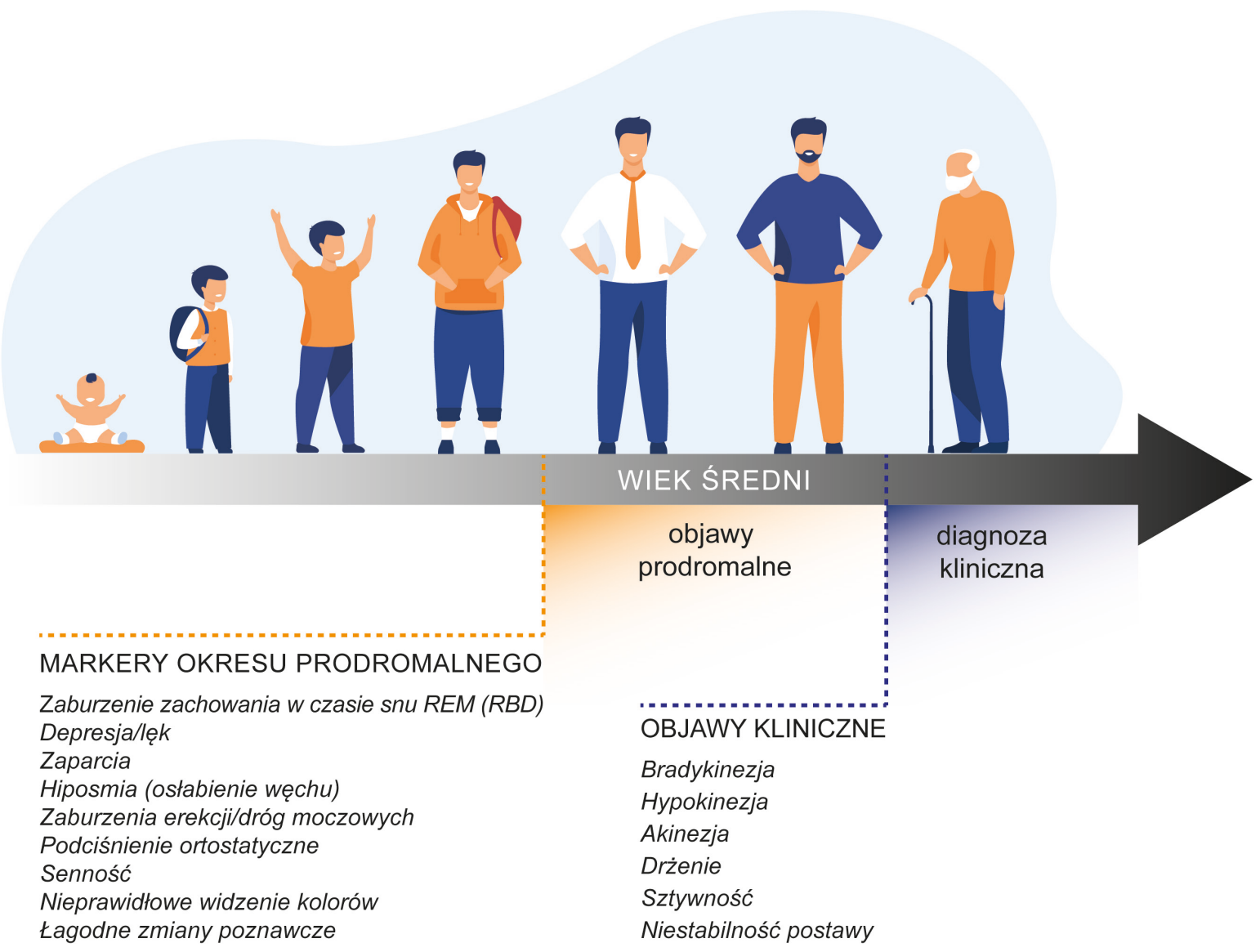

Ryc. 2. Główne objawy okresu prodromalnego i klinicznego w chorobie Parkinsona. Wiek średni ok 4060 lat; wykorzystano grafikę zaprojektowana przez pch.vector/Freepik. 
3. Fazę kliniczna - charakteryzujaca się obecnością parkinsonizmu, czyli bradykinezji ze spowolnieniem ruchowym/wyczerpaniem, plus jeden $z$ pozostałych objawów: drżenie spoczynkowe lub sztywność mięśniowa (Ryc. 2).

Podjęto próby wyliczenia współczynnika prawdopodobieństwa zachorowania na PD i opierając się na powyższych objawach i podziałach stwierdzono, że np. dla 50-letniego, zdrowego mężczyzny, który nie ma żadnych objawów, prawdopodobieństwo zachorowania wynosi 0,4\%. Jednak jeśli występuja u niego razem objawy takie jak: RBD, osłabienie węchu, depresja i zaparcia, wówczas ryzyko zachorowania wzrasta do 99\% (RoDRÍGUEZ-Violante i współaut. 2017).

Obraz kliniczny u pacjentów może być bardzo różnorodny, co pozwoliło na wyróżnienie różnych fenotypów klinicznych PD (THENGANATT i JANKOVIC 2014):

- akinetyczno-hipertoniczny, $z$ przewaga zaburzeń postawy i chodu (ang. postural instability and gait difficulty, PIGD), cechuje się głównie obecnościa bradykinezji i sztywności mięśniowej, szybkim postępem choroby i zazwyczaj rozpoczyna się po 60 r. życia (ang. late onset PD);

- $z$ dominujacym drżeniem (ang. tremor dominant, TD), charakteryzujacy się przewagą drżenia, mniejsza niepełnosprawnością w porównaniu do PIGD, o wolniejszym postępie choroby i wczesnym jej poczatku (zazwyczaj między 20-40 lat) (ang. young onset PD);

- typ mieszany, nieokreślony.

Zainteresowanie identyfikacja podtypów PD jest oparte na ich możliwym skojarzeniu $z$ etiologia lub prognozami postępu choroby oraz odpowiedzią na leczenie (THENGANATT i JANKOVIC 2014).

Główne objawy ruchowe w PD (drżenia, bradykinezja, sztywność mięśniowa) sa zazwyczaj początkowo jednostronne, dodatkowo pojawia się także między innymi mikrografia, zaburzenia mowy czy zubożenie mimiki twarzy. Niestabilność postawy, pochylona postawa (kamptokormia), zaburzenia chodu czy wręcz „zamrożenie " zwykle pojawiaja się w późniejszym okresie choroby. (Tabela 1).

Nawet jeśli PD było historycznie określane jako zaburzenie ruchowe, objawy pozaruchowe (NMS) sa ważnym aspektem obrazu klinicznego. NMS obejmuja ponad 30 różnych objawów, prawie w każdym układzie człowieka (Tabela 1), od zaburzenia połykania, ślinotoku po zaburzenia autonomiczne, żołądkowo-jelitowe, zaburzenia snu, poznawcze i neuropsychiatryczne (KRYGOWSKA-WAJS 2006, SŁAWEK i współaut. 2006, WIECZOREK i współaut. 2013, RODRÍGUEZ-VIOLANTE i współaut. 2017, SCHAPIRA i współaut. 2017, POSTUMA i BERG 2019, BALLESTRINO i SCHAPIRA 2020, ZHU i współaut. 2020). NMS sa zwykle rzadko zgłaszane przez pacjentów, jednak

Tabela 1. Główne objawy ruchowe i pozaruchowe w PD.

\begin{tabular}{|c|c|}
\hline Objawy ruchowe & Objawy pozaruchowe \\
\hline Drżenie spoczynkowe & $\begin{array}{l}\text { Objawy czuciowe - hiposmia (zaburzenia węchu), zabu- } \\
\text { rzenia widzenia kolorów, podwójne widzenie, ból }\end{array}$ \\
\hline Bradykinezja/hypokinezja/akinezja & $\begin{array}{l}\text { Objawy neuropsychiatryczne - depresja, lęk, apatia, ha- } \\
\text { lucynacje, psychozy }\end{array}$ \\
\hline Sztywność mięśniowa & Zaburzenia poznawcze, demencja \\
\hline $\begin{array}{l}\text { Zubożenie mimiki twarzy } \\
\text { (twarz maskowata tzw. „pokerzysty”) }\end{array}$ & $\begin{array}{l}\text { Zaburzenia snu i czuwania - RBD, RLS, bezsenność, } \\
\text { nadmierna senność w ciaggu dnia, }\end{array}$ \\
\hline $\begin{array}{l}\text { Mikrografia } \\
\text { (zmiana charakteru pisma, drobne, nierówne pismo) }\end{array}$ & $\begin{array}{l}\text { Zaburzenia w układzie moczowo-płciowym - zaburzenia } \\
\text { seksualne, obniżone libido, zwiększona częstotliwość od- } \\
\text { dawania moczu }\end{array}$ \\
\hline Niestabilność postawy (upadki) & $\begin{array}{l}\text { Objawy sercowo-naczyniowe - wahania ciśnienia krwi } \\
\text { (niedociśnienie posturalne, ortostatyczne, po posiłku), za- } \\
\text { burzenia zmienności rytmu serca }\end{array}$ \\
\hline $\begin{array}{l}\text { Nieprawidłowa pochylona postawa } \\
\text { (tzw. kamptokormia, zgięcie tułowia do przodu, } \\
\text { które ustępuje w pozycji leżącej a nasila } \\
\text { się podczas chodzenia) }\end{array}$ & $\begin{array}{l}\text { Zaburzenie w układzie pokarmowym - zaparcia, opóźnio- } \\
\text { ne/zmniejszone opróżnianie żołądka }\end{array}$ \\
\hline $\begin{array}{l}\text { Zaburzenia chodu czy wręcz „zamrożenie chodu” (ang. } \\
\text { „freezing”), zaburzenie stabilności postawy, trudności } \\
\text { w rozpoczęciu ruchu/pokonaniu przeszkody }\end{array}$ & $\begin{array}{l}\text { Inne: dysfagia (zaburzenia połykania), sialorrhoea (ślino- } \\
\text { tok), dyzartria (zaburzenia mowy), hipofonia (słaby głos, z } \\
\text { powodu braku koordynacji mięśni głosowych) }\end{array}$ \\
\hline
\end{tabular}

RBD - Zaburzenia zachowania w fazie snu REM; RLS - zespół niespokojnych nóg 
jeśli są odpowiednio zdiagnozowane, mają duży wpływ na zwiazana ze stanem zdrowia jakość życia i niepełnosprawność (SCHAPIRA i współaut. 2017, POSTUMA i BERG 2019, BALLESTRINO i SCHAPIRA 2020, ZHU i współaut. 2020). Niektóre inne objawy, określane jako „prodromalne/przedruchowe”, moga wystapić nawet 10 lat $i$ więcej przed pojawieniem się objawów motorycznych i rozpoznaniem klinicznym PD. Należą do nich osłabienie lub utrata węchu (hiposmia, anosmia), depresja, zaparcia i RBD, ale moga też obejmować zaburzenia wzrokowe, lęk i wiele innych zaburzeń, także autonomicznych (patrz Tabela1, Ryc. 2) (Postuma 2014, AL-QASSABI i wspó1aut. 2017, SCHAPIRA i współaut. 2017, POSTUMA i BERG 2019, HustAD i AASLY 2020, ZHU i współaut. 2020). Jednak wszyscy, aby zostać zdiagnozowanymi jako chorzy na PD, musza charakteryzować się głównymi cechami klinicznymi (Tabela 1, Ryc. 2) i dobra odpowiedzia na terapię podstawowym lekiem dopaminergicznym, L-DOPA, zwanym „złotym standardem".

Faza prodromalna PD stanowi jednak ogromna i wyjątkowa okazję do identyfikacji osób z wysokim ryzykiem zachorowania na PD, badania mechanizmów i postępu procesu neurodegeneracji, zanim zmiany patologiczne w mózgu doprowadza do zniszczenia powyżej 60\% neuronów dopaminowych w $\mathrm{SNc}$ oraz pojawienia się klinicznych objawów ruchowych. Dlatego w ostatnich kilkunastu latach badania, w tym duże populacyjne, skupiaja się na poszukiwaniu markerów fazy prodromalnej tej choroby, które moga poszerzyć możliwości terapeutyczne i umożliwić również zastosowanie terapii ochronnych (szczegółowy przegląd patrz POSTUMA i BERG 2019, UGRumov 2020). Ale dotychczas, mimo ogromnego postępu wiedzy o patofizjologii PD, poza leczeniem objawowym (od wielu lat głównie L-DOPA i leki stymulujace receptory dopaminergiczne D3/D2 jak ropinirol, pramipeksol), nie ma terapii, która zahamowałaby rozwój choroby (KRYGOWSKA-WAJS 2006, SŁAWEK 2014, ARMSTRONG i OKUN 2020, JANKOVIC i TAN 2020).

\section{ZABURZENIA SNU W PD}

Sen i regulacja cyklu czuwanie-sen należą do podstawowych funkcji mózgu. Prawidłowy fizjologiczny sen składa się $z 4$ faz, 3 faz "nie-REM" (sen wolnofalowy) i 1 fazy REM (ang. rapid eye movement), w której obserwuje się szybkie ruchy gałek ocznych i wysoka aktywność mózgu. Każdy cykl trwa ok. 90-100 min, a w nocy występuje zazwyczaj od 4-6 takich cykli (DORĘGOWSA i RUDZIŃSKA-BAR 2019). Regulacja procesów snu i czuwania jest bardzo złożonym zjawiskiem i polega na integracji funkcji różnych obszarów mózgu i neuroprzekaźników, z których wiele jest zaangażowanych również w PD (STEFANI i HöGL 2020).

Zaburzenia snu sa jednymi $z$ objawów najczęściej zgłaszanych przez pacjentów $z$ chorobami neurologicznymi (np. z padacz$\mathrm{ka}$, udarem czy zespołami otęiennymi i PD), a ich częstość rośnie $z$ czasem trwania choroby (LoUIS i współaut. 2017, SCHAPIRA i współaut. 2017, WIERZBICKA i współaut. 2017, Stefani i Högl 2020). Główne kategorie wybranych zaburzeń snu i Międzynarodowa Klasyfikację Zaburzeń Snu (CSD-3) można znaleźć np. w artykule WIERZBICKA i współaut. (2017).

W przypadku choroby Parkinsona stwierdzono, że zaburzenia snu należą do najczęstszych objawów pozaruchowych tej choroby, bowiem występuja u ok. 40-90\% pacjentów. Zaburzenia snu w PD moga pojawiać się w każdym stadium choroby, ale obserwuje się ich nasilenie wraz $z$ postępem objawów ruchowych (KUMAR i współaut. 2002, STEFANI i HöGL 2020). Kłopoty ze snem u pacjentów moga polegać zarówno na nadmiernej senności w ciągu dnia, bezsenności, obturacyjnym bezdechu sennym czy zaburzeniach zachowania w czasie snu REM i sa najczęściej zwiazane $z$ objawami choroby, ale moga być także niepożądanym skutkiem zażywanych leków (np. L-DOPA i agonistów dopaminowych). Różne czynniki, które nie maja ścisłego zwiazku $z$ choroba, moga także mieć wpływ na jakość snu, zaburzenia rytmu czy czuwania, takie jak: inne współistniejące choroby, procesy starzenia czy nieodpowiednia higiena snu (różne nawyki, które uniemożliwiają lub przeszkadzają w normalnym zasypianiu) (AL-QASSABI i współaut. 2017, SCHAPIRA i współaut. 2017, DOREGOWSKA i RUDZIŃSKA-BAR 2019, STEFANI i HÖGL 2020).

Wśród najważniejszych zaburzeń snu w PD znajduja się:

1. Bezsenność (ang. insomnia), czyli trudności $z$ zaśnięciem i utrzymaniem tego stanu; może również dochodzić do częstego wybudzania się w nocy, co jest dość powszechna dolegliwościa w rozwiniętej chorobie (częstość występowania ok. 60-80\%, zależnie od autorów). Ten rodzaj zaburzeń snu wydaje się mieć wieloczynnikowe podłoże, może bowiem być częściowo zwiazany z głównymi objawami choroby, takimi jak sztywność mięśniowa czy spowolnienie ruchowe, które np. moga utrudniać przewracanie się $z$ boku na bok i znalezienie wygodnej pozycji. Również drżenie spoczynkowe, jeden $z$ głównych objawów $\mathrm{PD}$, nie ułatwia procesu zasypiania, podobnie jak zaburzenia nastroju, depresja czy nykturia (częste oddawanie moczu w nocy). Także niektóre 
leki stosowane w leczeniu tej choroby, takie jak amantadyna czy selegilina, moga nasilać trudności $z$ zasypianiem. W porze nocnej następuje również przerwa w zażywaniu niektórych leków przeciwparkinsonowskich (m.in. L-DOPA), co może prowadzić do nasilenia objawów ruchowych i wystapienia kłopotów ze snem. Brak jest jednak dowodów na to, że bezsenność mogłaby być objawem okresu prodromalnego w PD (AL-QASSABI i współaut. 2017, SCHAPIRA i współaut. 2017, WIERZBICKA i współaut. 2017, DORĘGOWSKA i RUDZIŃSKA-BAR 2019, HUSTAD i AASLY 2020, STEFANI i HÖGL 2020);

2. Równie ważnym i częstym zaburzeniem snu jest nadmierna senność w ciągu dnia (ang. excessive daytime sleepness, EDS), występująca u ok. 30-40\% osób z PD, która może być spowodowana samym procesem chorobowym, współistniejacymi zaburzeniami snu, np. ciężka postacia RBD, czy też przyjmowanymi lekami (AL-QASSABI i współaut. 2017, DORĘGOWSKA i RUDZIŃSKA-BAR 2019, Hustad i AASLY 2020, STEFANI i HöGL 2020). Bowiem jej przyczyna moga być: zła jakość snu nocnego, np. $z$ powodu odczuwanego bólu, zaburzeń oddychania w czasie snu czy zespołu niespokojnych nóg (ang. restless legs syndrome, RLS), jak też przyjmowanie niektórych leków (AL-QASSABI i współaut. 2017, DORĘGOWSKA i RUDZIŃSKA-BAR 2019, HUSTAD i AASLY 2020). RLS pojawia się w przebiegu PD u ok. 20\% pacjentów i polega na przykrych doznaniach czuciowych w kończynach dolnych, głównie podczas siedzenia czy wieczornego odpoczynku, które moga ustępować przy poruszaniu nogami. Ponieważ objawy te pojawiaja się głównie w nocy, moga one stanowić przeszkodę w zaśnięciu. RLS może być też objawem PD, efektem niepożądanym działania leków, bądź samodzielnym schorzeniem (AL-QASSABI i współaut. 2017, HuSTAD i AASLY 2020).

Nadmierna senność w ciagu dnia polega na trudności w utrzymaniu stanu czuwania i niezamierzonych epizodach zapadania w sen; atak snu może wystąpić podczas normalnej aktywności i dlatego może być niebezpieczny, np. gdy wystapi w trakcie prowadzenia samochodu. Przyczyna EDS nie jest do końca poznana, sugeruje się jednak udział układu dopaminowego lub stosowanych leków przeciwparkinsonowskich (np. w porównaniu $z$ L-DOPA agoniści dopaminowi powoduja większa senność). Wyniki badań populacyjnych, w których oceniano EDS jako potencjalny objaw prodromalny w $\mathrm{PD}$, nie sa jasne, bowiem wykazywano nadmierna senność jako możliwy czynnik rozwoju choroby, ale $z$ kolei pacjenci $z$ nowo zdiagnozowaną PD nie mieli zwiększonej senności w porównaniu $z$ grupa kontrolną (AL-QASSABI i współaut. 2017, STEFANI i HÖGL 2020).

3. Na szczególna uwage zasługuje zaburzenie zachowania w czasie snu REM (ang. rapid eye movement sleep behavior disorder, RBD), należace do tzw. parasomnii snu REM, czyli grupy zaburzeń snu, które polegaja na występowaniu w trakcie snu lub przy wybudzaniu się, nieprawidłowych, niepożądanych i gwałtownych objawów ruchowych. Natomiast czas i jakość snu sa niezmienione. Do parasomnii zaliczamy także somnambulizm (sennowłóctwo, lunatyzm), lęki nocne, koszmary senne, katatrenię (jęk nocny) czy bruksizm (zgrzytanie zębami, patologiczne tarcie zębami żuchwy o zęby szczęki). Parasomnie sa częstymi zaburzeniami snu; opisanych jest ok. 80 różnych zaburzeń, każde $z$ nich występuje $z$ częstościa ok. 0,5-2\% w populacji ogólnej (MANNI i współaut. 2018).

RBD, które charakteryzuje się niekompletnie wykształcona faza snu REM, z okresowym zniesieniem fizjologicznej atonii mięśniowej, objawia się występowaniem dynamicznej aktywności ruchowej i/lub wokalizacji, odzwierciedlających przeżywane przez pacjenta marzenia senne, zarówno przykre, przerażające lub obojętne (PEEVER i współaut. 2014, Postuma 2014, Louis i współaut. 2017, WIERZBICKA i współaut. 2017, HÖGL i współaut. 2018, DORĘGOWSKA i RUDZIŃSKA-BAR 2019, Hustad i AASLY 2020, STEFANI i HöGL 2020). Pacjenci $z$ RBD odgrywają swoje sny $z$ różnym nasileniem, od łagodnych gestów dłoni, aż po gwałtowne zachowania, zawierajace elementy zagrożenia, niebezpieczeństwa (przemoc fizyczna, bicie, krzyki, bójka, ucieczka). W zwiąku $z$ tym, pojawiające się incydenty ruchowe moga prowadzić do poważnych urazów zarówno u chorego, jak też śpiącej $z$ nim osoby, bowiem pacjent może wypaść $z$ łóżka, zerwać się i uciekać przed siebie, kopać, boksować, szczypać, może też zranić siebie lub osobę $z$ nim śpiąca. Najczęstszymi sa urazy czy złamania kończyn, ale zdarzaja się też poważniejsze urazy głowy zwiazane $z$ upadkiem $z$ łóżka (Postuma 2014, WiERzBICKA i współaut. 2017, HÖGL i współaut. 2018, STEFANI i HöGL 2020). Z kolei wokalizacje przyjmuja postać nieartykułowanych dźwięków, krzyku, pojedynczych słów, w tym przekleństw lub złożonych wypowiedzi. W RBD raczej nie pojawia się zła jakość snu czy nadmierna senność w ciagu dnia. Jednak objawy moga mieć różny stopień nasilenia, od epizodu raz na kilka tygodni, aż do wielu epizodów nawet w ciagu jednej nocy (PEEVER i współaut. 2014, POSTUMA 2014, LOUIS i współaut. 2017, WiERZBICKA i współaut. 2017, HöGL i 
współaut. 2018, HUSTAD i AASLY 2020, STEFANI i HÖGL 2020).

Do badania zaburzeń snu, szczególnie RBD, używa się różnych testów i kwestionariuszy, np. Mayo Sleep Questionnaire, o bardzo wysokiej czułości i swoistości >90\% (POSTUMA 2014, DOREgGOWSKA i RUDZIŃSKA-BAR 2019), ale do postawienia diagnozy najlepszym i podstawowym badaniem jest tzw. całonocna polisomnografia, która składa się $z$ pomiaru: elektroencefalograficznego (EEG) rejestrującego bioelektryczną czynność mózgu, elektromiograficznego (EMG), w celu oceny funkcji mięśni (napięcie, rozluźnienie), elektrookulograficznego (EOG), do oceny prądów czynnościowych podczas ruchu gałek ocznych, oraz elektrokardiograficznego (EKG), badajacego aktywność elektryczna serca (DOREGOWSKA i RUDZIŃSKA-BAR 2019). W badaniach tych wykazano szereg patologii $\mathrm{u}$ chorych $\mathrm{z}$ PD, takich jak: spłycenie snu, częste wybudzanie (które może dotyczyć nawet $100 \%$ chorych w zaawansowanym stadium choroby), zmniejszoną ilość snu REM czy zwiększona latencję snu REM (PEEVER i współaut. 2014, Postuma 2014, LOUIS i współaut. 2017, HöGL i współaut. 2018, HUSTAD i AASLY 2020). Inne, jak np. zaburzenia zasypiania, sa rzadsze i występujac $z$ podobną częstotliwościa, jak w dobranych wiekowo grupach kontrolnych.

Historycznie RBD było klasyfikowane jako pierwotne/idiopatyczne, występujace przy braku innych współistniejacych chorób (obecnie określa się raczej mianem formy izolowanej, HöGL i współaut. 2018), oraz jako wtórne RBD, gdy jest wywoływane przez leki lub jest zwiazane $z$ innymi zaburzeniami neurologicznymi lub neurodegeneracyjnymi, chorobami autoimmunologicznymi lub uszkodzeniami pnia mózgu (PEEVER i współaut. 2014, LOUIS i współaut. 2017, HÖGL i współaut. 2018, STEFANI i HöGL 2020). Wtórna forma RBD może również wiazać się z zatruciem lub odstawieniem od alkoholu $i$ innych substancji psychotropowych i jest częstym schorzeniem związanym $z$ długotrwałym stosowaniem leków przeciwdepresyjnych. Pacjenci przyjmujacy selektywne inhibitory wychwytu zwrotnego serotoniny (ang. selective serotonin reuptake inhibitors, SSRI) sa narażeni na zwiększone ryzyko wystapienia wtórnej RBD (PEEVER i współaut. 2014). RBD jest również powszechne w narkolepsji (PEever i współaut. 2014).

Badania wykazały, że u $>80 \%$ pacjentów $z$ RBD w ciagu dekady lub więcej rozwinie się PD, DLB lub MSA (BOEVE 2013, GALBIATI i współaut. 2019). Ta jednostka chorobowa może także występować w innych schorzeniach neurodegeneracyjnych, takich jak: porażenie nadjądrowe, ALS, ataksja rdzenio- wo-móżdżkowa, limbiczne zapalenie mózgu lub zespół Guam (IRANZO i współaut. 2014, POSTUMA 2014, LOUIS i współaut. 2017, GALBIATI i współaut. 2019). Obecnie uważa się więc, że RBD nie jest jedynie parasomnia, ale raczej objawem wczesnej fazy a-synukleinopatii. Wykazano, że RBD, która jest przewlekła, progresywna choroba, zwykle dotyczy ok. 0,5\% ogólnej populacji w wieku powyżej 50 lat. Najbardziej kompleksowe badania przesiewowe pod katem utraty atonii snu REM w populacji ogólnej >60 r.̇̇. szacują jednak częstość występowania na poziomie $1,2 \%$ dla objawowej RBD, potwierdzonej $\mathrm{w}$ badaniu polisomnograficznym, i do $5 \%$ dla bezobjawowej utraty atonii REM (patrz: AL-QASSABI i współaut. 2017, GALBIATI i współaut. 2019).

Wiadomo także, że w procesy czuwania i snu (REM i nie-REM), a także w zaburzenia snu, np. RBD, zaangażowane sa różne neuroprzekaźniki, w tym dopamina, serotonina, noradrenalina, histamina, acetylocholina, glutaminian czy hipokretyna (oreksyna), która jest produkowana przez tylno-boczne podwzgórze i ma działanie pobudzajace; jest „włacczona” (ang. „on”) w stanie czuwania i "wyłączona” (ang. „off”) podczas snu REM i nie-REM (BROOKS i PEEVER 2012, FRAIGNE i współaut. 2015). Jednak mechanizm powstawania RBD jest dość słabo poznany.

\section{OBWODY NEURONALNE ZAANGAŻOWANE W SEN REM I RBD}

RBD, jak wcześniej wspomniano, jest zwykle spowodowane synukleinopatia w strukturach pnia mózgu. Wiadomo jest, że przyczyna RBD jest niekompletne wykształcenie fazy snu REM, $z$ okresowym zniesieniem fizjologicznej atonii mięśniowej, zwiąane $z$ uszkodzeniem przede wszystkim struktur w dolnej części pnia mózgu (Ryc. 3). Prawidłowa atonia REM jest bowiem kontrolowana głównie przez obwody neuronalne umiejscowione $\mathrm{w}$ dolnym moście i rdzeniu przedłużonym (ang. pons, medulla oblongata), a zaczyna się w okolicy miejsca sinawego - jadrze podsinawym (ang. locus coeruleus - nucleus subcoeruleus, LC - SubC) i okolicy mostu, który wysyła projekcje do rdzenia przedłużonego. Jacdro SubC jest zwane również jądrem boczno-grzbietowym nakrywki (ang. sublaterodorsal tegmental nucleus, SLD) i obszar ten jest aktywny głównie w czasie epizodów snu REM (Ryc. 3) (MUNTEAN i współaut. 2014, PEEVER i współaut. 2014, FRAIGNE i współaut. 2015, MCKENNA i PEEVER 2017). Komórki jądra SLD sa bardziej aktywne podczas snu REM niż podczas snu nie-REM i budzenia się (MUNTEAN i współaut. 2014, PeEver i współaut. 2014, MCKennA 


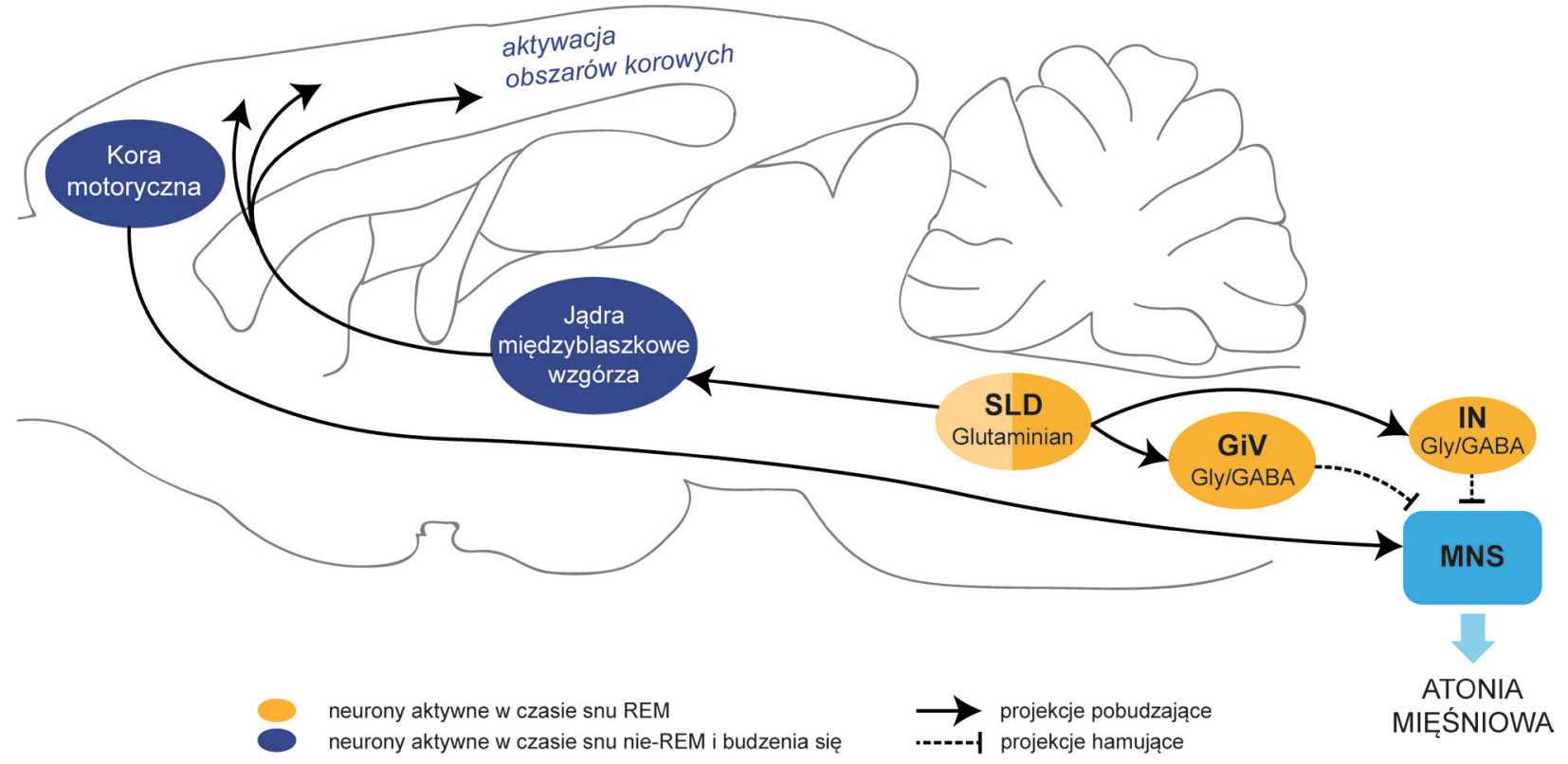

Ryc. 3. Uproszczony schemat obwodów neuronalnych i struktur mózgowych zaangażowanych w kontrolę motoryczną w fazie snu REM oraz w RBD.

GABA - kwas $\gamma$-aminomasłowy, GiV - brzuszne i wielkokomórkowe jądro siateczkowate, Gly - glicyna, IN - interneurony, MNS - neurony ruchowe rdzenia, SLD - jądro boczno-grzbietowe nakrywki (opis w tekście).

i PEEver 2017). Większość $z$ tych komórek syntetyzuje glutaminian i ich stymulacja wyzwala atonię mięśniową. Z kolei niewielkie, obustronne uszkodzenia jądra SLD skutkują utratą atonii snu REM i późniejszymi objawami RBD, natomiast maja one znikomy wpływ na ilość snu REM. W przeciwieństwie do tego, duże uszkodzenia tego jadra nie tylko zapobiegaja atonii snu REM, ale także wpływają na ilość snu i czas trwania snu REM (PEEVER i współaut. 2014). Wyniki te wskazuja zatem, że atonia snu REM i sam sen REM sa kontrolowane przez dwie populacje neuronów SLD. Jedna - odpowiedzialna za atonię snu REM, a druga - kontrolujaca czas snu REM i wywołujaca aktywację kory mózgowej podczas snu REM. Ponieważ jednak architektura snu REM nie jest zmieniona w RBD, wskazuje to, że tylko ta jedna populacja komórek SLD, kontrolujacych atonię snu REM, jest uszkodzona w RBD (Ryc. 3) (FRAIGNE i współaut. 2015, HöGL i współaut. 2018, PEEVER i współaut. 2014).

Sugeruje się, że komórki SLD aktywuja neurony GABAergiczne oraz zawierajace glicynę w brzusznym i wielkokomórkowym jądrze siateczkowatym (ang. ventral and gigantocellular reticular nucleus, GIV), jak też w brzusznej części tworu siatkowatego rdzenia przedłużonego (ang. ventral medullary reticular formation), które $z$ kolei wywołuja atonię snu REM bezpośrednio hamujac neurony ruchowe rdzenia kręowego (MNS) (Ryc. 3) (Muntean i współaut. 2014, PEEVER i współaut. 2014, FRAIGNE i współaut. 2015, MCKenNa i PEever 2017, Li i współaut. 2018, HöGL i współaut. 2018). W tych procesach biora udział również neurony noradrenergiczne LC i serotoninergiczne jąder szwu (ang. nucleus raphe), które dodatkowo wspomagaja zjawisko atonii podczas snu REM.

Istnieja dowody na udział także innych struktur, jak m.in. jądra czerwiennego (ang. red nucleus), jacdra grzbietowo-bocznego nakrywki (ang. laterodorsal tegmental nucleus) i jadra konarowo-mostowego (ang. pedunculopontine nuleus). Aktywacja tych obwodów neuronalnych może wyjaśnić np. niektóre gwałtowne ruchy w RBD. Ponieważ jednak te ruchy sa często skoordynowane i przypominaja ruchy dowolne podczas czuwania (np. gesty specyficzne dla danej kultury) sugeruje się, że również kora motoryczna (ang. motor cortex) jest zaangażowana $\mathrm{w}$ te procesy (Ryc. 3). Hipotezę tę potwierdza fakt, że neurony piramidowe kory (ang. pyramidal tract neurons), które uczestnicza w ruchach dowolnych kończyn, sa bardzo aktywne zarówno podczas czuwania, jak i podczas snu REM (Muntean i współaut. 2014, PEEVER i współaut. 2014, MCKENNA i PEEVER 2017, HÖGL i współaut. 2018,). 
Opisane powyżej struktury, których uszkodzenie prowadzi w konsekwencji do braku atonii $\mathrm{w}$ RBD, oraz obecność wtrętów a-syn w strukturach pnia mózgu wskazuje na to, że te procesy neurodegeneracyjne wydaja się być chronologicznie zgodne ze stadiami rozwoju PD według Braaka (BRAAK i współaut. 2003, 2004; BOEVE 2013; DEL TREDICI i BRAAK 2016). Bowiem RBD, jako wczesny objaw okresu prodromalnego PD, jest związany ze zmianami w dolnej części pnia mózgu, w tym w SLD/SubC, co odpowiada stadium 1-2, zanim jeszcze degeneracji ulegna neurony SNc (stadia 3-4). Później proces neurodegeneracyjny rozprzestrzenia się na obszary przodomózgowia i wreszcie kory mózgowej (stadia 5-6). Jednak opóźnienie czasowe między wystapieniem synukleinopatii $\mathrm{w}$ RBD a pojawieniem się jej objawów, jak też rozszerzeniem się procesu neurodegeneracji i wystapieniem objawów PD, może się różnić $\mathrm{w}$ zależności od konkretnego przypadku od miesięcy nawet do wielu lat.

\section{LECZENIE RBD}

Podstawowym czynnikiem leczenia jest zapewnienie pacjentom $z$ RBD bezpiecznego miejsca do spania dla nich i ich partnerów. Ważne jest, aby doradzać im jak unikać potencjalnie niebezpiecznych i mogacych zranić przedmiotów w pobliżu, np. broni palnej lub przedmiotów szklanych. Partnerzy powinni być też pouczeni o chorobie i fakcie braku przez chorego kontroli nad zachowaniem w czasie snu. W ciężkich przypadkach wskazane może być też samodzielne spanie. Pacjentom można też zalecić zaprzestanie stosowania leków przeciwdepresyjnych, o których wiadomo, że powodują lub nasilaja RBD (DOREGOWSKA i RUDZIŃSKA-BAR 2019, STEFANI i HÖGL 2020).

Jeśli chodzi o leczenie farmakologiczne, to $\mathrm{w}$ obszernym przegladzie opcji terapeutycznych w RBD i innych parasomniach wskazano na melatoninę i klonazepam w niskich dawkach, jako najlepsze leki używane w leczeniu tych schorzeń (MANNI i współaut. 2018). Jednak lekiem pierwszego rzutu wydaje się być raczej melatonina, której mechanizm działania nie jest do końca jasny, ale nasila ona atonię REM i redukuje epizody RBD, szczególnie, że nie wywołuje tak poważnych i licznych skutków ubocznych. Dane badawcze wykazały, że klonazepam poprawiał w sposób umiarkowany objawy RBD u co najmniej $78 \%$ osób, podczas gdy tylko 48\% osób używajacych melatoninę uległo poprawie (AL-QASSABI i współaut. 2017). Z drugiej strony jednak, melatonina jest lepiej tolerowana przez pacjentów, a jej głównym efektem ubocznym jest senność w ciagu dnia, sporadycznie apatia czy poranne bóle głowy. Natomiast klonazepam, szczególnie w wysokich dawkach, powoduje nadmierna sedacje, upośledza funkcje poznawcze i zwiększa ryzyko upadków, dlatego należy go stosować ostrożnie u osób ze wspólistniejacymi zaburzeniami poznawczymi, zaburzeniami chodu lub innymi przyczynami senności. Lista skutków ubocznych klonazepamu jest szczególnie niepokojaca, ponieważ sa to również częste objawy synukleinopatii neurodegeneracyjnych (AL-QASSABI i współaut. 2017, MANNI i współaut. 2018).

W badaniu polisomnograficznym wykazano również, że rotygotyna (agonista receptorów dopaminowych stosowany $\mathrm{w}$ leczeniu PD) poprawia RBD. Z kolei $\mathrm{w}$ badaniu pilotażowym $\mathrm{z}$ udziałem 12 pacjentów stwierdzono zmniejszenie częstości epizodów RBD po zastosowaniu rywastygminy (lek stosowany w AD) (STEFANi i Högl 2020). Próbowano też wielu innych leków $\mathrm{z}$ różnych grup, np. lorazepam, zolpidem, zopiklon, donepezil, ramelteon, agomelatyna, kanabinoidy, a także pramipeksol (agonista receptorów dopaminowych D3/D2, stosowany $\mathrm{w}$ klinice $\mathrm{w}$ leczeniu PD), pod katem łagodzenia objawów RBD, jednak większość $z$ nich nie przynosiła poprawy lub wykazywała niski poziom skuteczności (AL-QASSABI i współaut. 2017, STEFANI i HÖGL 2020).

\section{RBD JAKO MOŻLIWY MARKER PRODROMALNEJ FAZY PD}

Najważniejszym jednak aspektem w przypadku tego zaburzenia snu jest to, że jak dotą RBD wydaje się być najbardziej specyficznym, prodromalnym markerem PD i innych synukleinopatii, bowiem nawet takie objawy pozaruchowe jak osłabienie węchu, zaparcia czy depresja, a więc ważne symptomy, mogace prognozować pojawienie się PD w przyszłości, występuja jedynie u $1 / 3$ populacji ogólnej (POSTUMA 2014, AL-QASSABI i współaut. 2017, LOUIS i współaut. 2017, RoDRíGUEZ-VIOLANTE i współaut. 2017). Natomiast $\mathrm{u}$ pacjentów $\mathrm{z}$ RBD wykazano $>80 \%$ ryzyko rozwoju synukleinopatii neurodegeneracyjnej. W badaniach przesiewowych i metaanalizach oszacowano ogólna czestość występowania RBD w PD na ok. 30-50\%. Jednak Postuma i współaut. (2015b) obserwowali, że po trzech latach $25 \%$ pacjentów $z$ RBD zachorowało na $\mathrm{PD}$, ale po pięciu latach od diagnozy już 41\% miało PD. Stwierdzono także, że ok. $45 \%$ pacjentów $z$ RBD rozwinęło zaburzenie neurologiczne $\mathrm{w}$ ciagu średnio 11,5 lat od diagnozy (RodRíGUEZ-VIOLANTE i współaut. 2017). Ostatnie dane wskazuja, że ryzyko wystapienia PD, od momentu rozpoznania RBD, wynosi prawie $76 \%$ 
po 10 latach i $91 \%$ po 14 latach (IRANZO i współaut. 2014). W innych chorobach neurodegeneracyjnych $\mathrm{RBD}$ występuje równie lub nawet częściej, bowiem wykazano je u $80 \%$ przypadków chorych z LBD i u 90\% chorych $z$ MSA (POSTUMA 2014, AL-QASSABI i współaut. 2017). Ponadto, 95\% pacjentów $Z$ RBD i choroba neurodegeneracyjna wykazuje obecność synukleinopatii (Postuma 2014, AL-QASSABI i współaut. 2017, LOUIS i współaut. 2017).

Zatem badania RBD moga dostarczyć informacji o najwcześniejszych stadiach chorób neurodegeneracyjnych (synukleinopatii) i mechanizmach leżacych u ich podłoża, w tym PD, a główne konsekwencje obejmuja m.in. możliwość znalezienia leków o działaniu neuroprotekcyjnym, w celu zahamowania postępu choroby i nie dopuszczenia do dużych ubytków neuronów dopaminowych w SNc. Pozostaje to niestety nadal w sferze niezrealizowanych celów, bowiem obecnie nie sa znane żadne leki, które mogłyby spowalniać lub zatrzymać postęp choroby.

\section{PODSUMOWANIE}

Choroba Parkinsona jest jedna $z$ najczęściej występujacych chorób neurodegeneracyjnych w dobie starzejacych się społeczeństw. Niestety, mimo ogromnego postępu w zrozumieniu mechanizmów leżących u jej podstaw, nadal nie jest dostepna terapia, która zatrzymałaby lub spowolniła jej postęp. Dlatego w ostatnich latach ogromnym zainteresowaniem naukowców i klinicystów ciesza się badania, których celem jest poszukiwanie biomarkerów PD, szczególnie jej wczesnej, prodromalnej fazy, czyli zanim uszkodzeniu ulegnie $>60 \%$ neuronow dopaminowych w SNc i rozwina się kliniczne objawy ruchowe (bradykinezja, sztywność mięśniowa, drżenia, zaburzenia postawy i chodu).

Bezsenność, nadmierna senność w ciągu dnia czy zaburzenie zachowania w fazie REM (RBD) sa częstymi zaburzeniami snu w różnych synukleinopatiach, w tym także w PD. Szczególnie RBD, jako jeden $z$ częstych objawów pozaruchowych w PD wydaja się być ciekawym, potencjalnym markerem okresu prodromalnego w PD, bowiem w ok. $80 \%$ przypadków poprzedza on rozwój synukleinopatii, takich jak PD czy LBD. Sugeruje to, że procesy neurodegeneracyjne w poczatkowym okresie (stadia 1-2 wg Braaka) sa ukierunkowane na obwody neuronalne i struktury zaangażowane w sen REM i zwiazane $z$ nim zaburzenia, takie jak RBD. Zarówno dane kliniczne, jak też wyniki badań podstawowych dostarczyły dowodów wskazujących, że u podstaw RBD leżą zaburzenia sieci neuronalnej, odpowiadające za regulację fizjologicznej atonii snu REM. Otwiera to nowe możliwości leczenia RBD i zrozumienia jego zwiazku $z$ chorobami neurodegeneracyjnymi, w tym PD. Jak dotychczas bowiem, RBD potwierdzone polisomnograficznie, ma zdecydowanie najwyższa specyficzność i pozytywna wartość predykcyjna spośród wszystkich markerów prodromalnego okresu PD. Natomiast pacjenci $z$ RBD moga stanowić idealna grupę do badania potencjalnych terapii neuroprotekcyjnych, bowiem sa na wystarczajaco wczesnym etapie procesu neurodegeneracji, a także nie sa jeszcze leczeni żadna terapia objawowa PD lub demencji, która mogłaby zakłócać interpretację wyników tych badań.

\section{Streszczenie}

Choroba Parkinsona (PD) jest jedną $z$ najczęściej występujących chorób neurodegeneracyjnych we współczesnym świecie, zwiazana ze starzejącymi się społeczeństwami. PD jest choroba postępujaca, w której dochodzi do utraty neuronów dopaminowych istoty czarnej (SN), a cecha patologiczna jest obecność ciał Lewy'ego, złożonych m.in. z białka a-synukleiny. Gdy utrata neuronów w SN przekroczy ok. $60 \%$, pojawiaja się główne objawy kliniczne (ruchowe), czyli bradykinezja, sztywność mięśniowa, drżenie spoczynkowe oraz zaburzenia postawy i chodu. PD jest choroba o złożonej etiopatogenezie, w której bardzo ważny jest okres przedkliniczny/prodromalny, bowiem pojawiaja się wówczas objawy pozaruchowe, np. osłabienie węchu, depresja czy zaburzenia snu, wyprzedzające nawet o kilkanaście lat fazę kliniczna. Niniejsza praca, poza przedstawieniem podstawowych informacji na temat PD, skupia się na zaburzeniach snu, wśród których najważniejszym jest zaburzenie zachowania w czasie snu REM, które może stanowić wczesny marker diagnostyczny rozwijającej się choroby, a tym samym pomóc $\mathrm{w}$ poszukiwaniu nowych terapii neuroprotekcyjnych już na wczesnym, prodromalnym etapie.

\section{LITERATURA}

Al-QAssabi A., Fereshtehnejad S.M., Postuma R. B., 2017. Sleep disturbances in the prodromal stage of Parkinsons disease. Curr. Treat. Options Neurol. 19, doi: 10.1007/s11940-0170458-1

ARMSTRONG M. J., OKUn M. S., 2020. Diagnosis and treatment of Parkinson's disease. A review. JAMA 323, 548-560.

Ascherio A., SchWARZSCHILDE M. A., 2016. The epidemiology of Parkinson's disease: risk factors and prevention. Lancet Neurol. 15, 12571272.

BAllestrino R., SchapiRa A. V. H., 2020, Parkinson disease. Eur. J. Neurol. 27, 27-42.

Blesa J., Trigo-Damas i., Dileone M., Del Rey N-G., HeRnandeZ L. F., OBeso J. A., 2017. Compensatory mechanism in Parkinson's disease: circuits adaptations and role in disease modification. Exp. Neurol. 298, 148-161.

Berg D., Postuma R. B., Adler Ch. H., Bloem B. R., CHAN P. i współaut., 2015. MDS research criteria for prodromal Parkinson's disease. Mov. Disord. 30, 1600-1611.

Boeve B. F., 2013. Idiopathic REM Sleep Behavior Disorder in the development of Parkinson's disease. Lancet Neurol. 12, 469-482. 
BraAK H., Del TREdici K., Rub U., De Vos R.A.I., JANSEEN STEUR E. N. H., BRAAK E., 2003. Staging of brain pathology related to spora dic Parkinson's disease. Neurobiol. Aging 24, 197-211.

BraAK H., GHebremedhin E., Rub U., BratzKe H., DEL TREDICI K., 2004. Stages in the development of Parkinson's disease-related pathology. Cell Tissue Res. 318, 121-134.

BROOKS P. L., PEEVER J. H., 2012. Identification of the transmitter and receptor mechanisms responsible for REM sleep paralysis. J. Neurosci. 32, 9785-9795.

DEL TREDICI K., BRAAK H., 2016. Sporadic Parkinson's disease: development and distribution of a-synuclein pathology. Neuropathol. Appl. Neurobiol. 42, 33-50.

DOREGOWSKA M., RUDZIŃSKA-BAR M., 2019. Zabu rzenia snu $w$ chorobie Parkinsona. Wiad. Lek. $72,425-431$

Elfil M., Kamel S., Kandil M., KoO B. B., SCHAEFER S. M., 2020. Implications of the gut microbiome in Parkinson's Disease. Mov. Disord. 35, 921-933.

Fraigne J. J., ToRontali Z. A., Snow M. B., PeEVER J. H., 2015. REM Sleep at its core - circuits, neurotransmitters, and pathophysiology. Front Neurol. 6, 123.

Galbiati A., Verga L., Giora E., Zucconi M., FeRINI-STRAMBI L., 2019. The risk of neurodegeneration in REM sleep behavior disorder: a systematic review and meta-analysis of longitudinal studies. Sleep Med. Rev. 43, 37-46.

GoldMAN J. G., GUERRA C. M., 2020. Treatment of nonmotor symptoms associated with Parkinson disease. Neurol. Clin. 38, 269-292.

Högl B., STEFANi A., Videnovic A., 2018. İ̄iopathic REM sleep behaviour disorder and neurodegeneration - an update. Nat. Rev. Neurol. $14,40-55$.

Hustad E., Aasly J. O., 2020. Clinical and imaging markers of prodromal Parkinson's disease. Front. Neurol. 11, 395.

IRANZO A., FERnANDEZ-ARCos A., TOlOSA E., SERRADEll M., MOlinUeVo J. L., VAlldeORIOla F., GelPi E., Vilaseca I., SANCHEZ-VAlle R., LlaDO A., GAIG C., SANTAMARIA J., 2014. Neurodegenerative disorder risk in idiopathic REM Sleep Behavior Disorder: Study in 174 patients. PLoS One, 9, e89741.

JANKOVIC J., TAN E.-K., 2020. Parkinson's disease: ethiopathogenesis and treatment. J. Neurol. Neurosurg. Psychiatry 91, 795-808.

KILZHEIMER A., HENTRICH T., BURKHARDT S. AND SCHUlZE-HENTRICH J. M., 2019. The challenge and opportunity to diagnose Parkinson's disease in midlife. Front. Neurol. 10, 1328.

KRYGOWSKA-WAJS A., 2006. Przedkliniczny $i$ wczesny okres choroby Parkinsona - diagnostyka $i$ możliwości leczenia neuroprotekcyjnego. Pol. Przeglad Neurol. 2, 177-182.

KumAR S., BHATIA M., BEHARI M., 2002. Sleep di sorders in Parkinson's disease. Mov. Disord. 17, 775-781.

Li M., WANG L., LIU J. H., ZHAN S. Q., 2018. Relationships between rapid eye movement sleep behavior disorder and neurodegenerative diseases: clinical assessments, biomarkers, and treatment. Chin. Med. J. 131, 966-973.

Louis E. K. ST., Boeve A. R., Boeve B. F., 2017. REM sleep behavior disorder in Parkinson's disease and other synucleinopathies. Mov. Disord. 32, 645-658.

MANNI R., TOSCANO G., TERZAGHI M., 2018. Therapeutic symptomatic strategies in the parasom- nias. Curr. Treat. Options Neurol. 20, doi: $0.1007 / \mathrm{s} 11940-018-0508-3$.

MCCANN H., CARTWRIGHT H., HALliday G. M., 2016. Neuropathology of a-synuclein propagation and Braak hypothesis. Mov Disord, 31, 152-160.

McKenna D., Peever J., 2017. Degeneration of Rapid Eye Movement Sleep Circuitry underlies Rapid Eye Movement Sleep Behavior Disorder. Mov. Disord. 32, 636-644.

Munoz A., LOPEZ-LOPEZ A., LABANDEIRA C. M., LABANDEIRA-GARCIA J. L., 2020. Interactions between the serotonergic and other neurotransmitter systems in the basal ganglia: role in Parkinson's disease and adverse effects of $L$-DOPA. Front. Neuroanat. 14, 26.

MunTEAN M.-L., SiXEl-DöRING F., TRENKWALder C., 2014. REM sleep behawior disorder in Parkinson's disease. J. Neural Transm. 121, 41-47.

Obeso J. A., Stamelou M., Goetz C. G., PoEWE W., LANG A. E. i współaut., 2017. Past, present, and future of Parkinson's disease: a special essay on the 200th anniversary of the shaking palsy. Mov. Disord. 32, 1264-1310.

PeEver J., LupPI P.-H., MonTPlaisiR J., 2014. Breakdown in REM sleep circuitry underlies REM sleep behavior disorder. Trends Neurosci. 37, 279-288.

Postuma R. B., 2014. Prodromal Parkinson's disease - using REM sleep behawior disorder as a window. Park. Rel. Disord. Suppl. 1, S1S4.

Postuma R. B., Berg D., 2019. Prodromal Parkinson's disease the decade past, the decade to come. Mov. Disord. 34, 665-675.

Postuma R. B., BerG D., STERN M., POEWe W., Olanow C. W. i współaut., 2015a. MDS Clinical Diagnostic Criteria for Parkinson's Disease. Mov. Disord. 30, 1591-1599.

Postuma R. B., IRANZO A., Hogl B., ARnulf I., FERINI-STRAMBI L. i współaut., 2015b. Risk factors for neurodegeneration in idiopathic ra pid eye movement sleep behavior disorder: a multicenter study. Ann. Neurol. 77, 830-839.

RODRÍGUEZ-VIOLANTE M., ZERÓN-MARTÍNEZ R., CERVANTES-ARRIAGA A., CORONA T., 2017. Who can diagnose Parkinson's disease first? Role of pre-motor symptoms. Arch. Med. Res. 48, 221-227.

SCHAPIRA A. H. V., CHAUdHuRI K. R., JENNER P., 2017. Non-motor features of Parkinson disease. Nat. Rev. Neurosci. 18, 435-450.

SŁAWEK J., 2014. Choroba Parkinsona - jak właściwie rozpoznawać, skutecznie $i$ bezpiecznie leczyć? Forum Med. Rodzinnej, 8, 281-291.

SŁAWEK J., JASIŃSKA-MYGA B., WIECZOREK D., 2006. Zaburzenia poznawcze $w$ chorobie Parkinsona. Pol. Przeglad Neurol. 2, 203-209.

Stefani A., Högl B., 2020. Sleep in Parkinson's disease. Neuropsychopharmacology 45, 121128.

ThenganatT M. A., JANkOVIC J., 2014. Parkinson disease subtypes. JAMA Neurol. 71, 499-504.

UGRUMOV M., 2020. Development of early diagnosis of Parkinson's disease: illusion or reality? CNS Neurosci. Ther., doi:10.1111/cns.13429.

WiecZoreK D., SiteK E.J., WóJCIK J., SŁAWEK J., 2013. Eagodne zaburzenia funkcji poznaw czych $i$ otepienie $w$ chorobie Parkinsona - obraz kliniczny $i$ aktualne kryteria diagnostyczne. Pol. Przeglad Neurol. 9, 96-104.

WIERZBICKA A., WICHNIAK A., JERNAJCZYK W. 2017. Rola zaburzeń snu $w$ etiologii innych chorób neurologicznych. Neurologia po Dyplomie, https://podyplomie.pl/neurologia/2- 
8440, rola-zaburzen-snu-w-etiologii-innychchorob-neurologicznych.

ZHU J., ZHONG M., YAN J., JiANG X., Wu Z., PAN Y., Shen B., Zhang L., DONG J., ZHANG L.,
2020. Nonmotor symptoms affect sleep quality in early-stage Parkinson's disease patients with or without cognitive dysfunction. Front. Neurol. 11, doi:10.3389/fneur.2020.00292

KOSMOS Vol. 69, 3, 509-521, 2020

\author{
JADWIGA WARDAS, BARBARA KOSMOWSKA
}

Department of Neuropsychopharmacology, Maj Institute of Pharmacology PAS, 12 Smetna Str., 31-343 Kraków,

E-mail: wardas@if-pan.krakow.pl

\title{
REM SLEEP BEHAVIOR DISORDERS AS AN EARLY MARKER OF PARKINSON'S DISEASE
}

\section{Summary}

Parkinson's disease (PD) is one of the most common neurodegenerative diseases in the modern world and is associated with aging societies. PD is a progressive disease in which there is a loss of dopamine neurons of the substantia nigra (SN), and the pathological feature is the presence of Lewy bodies, composed of, among others, the protein a-synuclein. When the loss of neurons in SN exceeds approx. 60\%, the main clinical (motor) symptoms appear, such as bradykinesia, muscle stiffness, resting tremor and posture and gait disturbances. PD is a disease with a complex etiopathogenesis, in which the preclinical/prodromal period is very important, because non-motor symptoms appear, such as olfactory impairment, depression or sleep disorders, even several years ahead of the clinical phase. In addition to presenting basic information on PD, this work focuses on sleep disorders, the most important of which is REM sleep behavior disorder, which may be an early diagnostic marker of the developing disease, and thus help in the search for new neuroprotective therapies at an early prodromal stage.

Key words: motor symptoms, neurodegenerative diseases, non-motor symptoms, Parkinson's disease, prodromal phase, RBD REM sleep behavior disorders, sleep disorders 